\title{
歯科用レジンの重合時に発生する内部応力に関する研究
}

\author{
九州米科大学大学院歯学研究科第一補経学専攻 (指導 : 豊田静夫教授) \\ 三 宅 茂 樹 \\ 昭和53年 1 月 28 日受付
}

\begin{abstract}
(本論文の要旨は, 昭和51年 9 月25日の第63回日本補棳雨科学会総会, 昭和52年 5 月21日の第37回九州歯科学 会総会において発表した。)
\end{abstract}

\section{Studies on the Inner Stress as Produced in Curing Process of Resin Preparations for Dental Use}

By

\author{
Shigeki Miyake \\ First Department of Prosthetic Dentistry (Director : Prof. Shizuo Toyoda) \\ Kyushu Dental College, Kitakyushu, Japan
}

It dates back more than 40 years ago that acrylic resin was introduced to the field of clinical dentistry. During these 40 years, a variety of resin materials such as self curing resin, heat shock resin and pour resin were newly developed, and many investigations were also undertaken in pursuit of most faverable imbedding (core making) and heating cycle.

In the present paper, a series of experiments was described which compared the inner stress as produced in the curing process of different procedures of core making. Results were summarized as follows :

1 ) Production of inner stress was minimum at initial stage of mixing of resin when it was fluid, so that most of the inner stress was to be produced after the resin became rigid to certain extent.

2 ) The value for the specific volume measured after polymerization was lower with the heat curing type resin than with the self curing resin, while the $\mathrm{Tg}$ measured for the former was higher than that for the latter resin.

3 ) The specific volume measured on resins as polymerized by the silicone core method gave smaller values as compared with that resins polymerized by the plaster core method, and Tg was higher the former type resins than the latter ones.

4) When Cast Resin (pour resin) was used for experiment, the specific volume obtained was smaller than that obtained in the press type, while Tg obtained was not affected in the least with use of this resin.

5 ) Measurment on the dimensional accuracy showed better result with use of self curing resin than with heat curing type resin, and the rate of shrincage with the former type resin was within the range between $1 / 2$ to $1 / 3$ of that with the latter, 
in spite that plaster imbedding or silicone core methods were applied.

6 ) When polymerized resins were kept at high temperatures, release of the inner stress was faster and deformation much greater.

7 ) The self curing resins as polymerized by the plaster core method exhibited lower values of $\mathrm{Tg}$ and greater specific volumes, though the dimensional accuracy was excellent. An improvement on the polymerizing method (silicone core method), however, proved to be able to raise the value of $\mathrm{Tg}$ as well as lower the value of specific volume with the self curing resin.

8 ) As stated above, the silicone core method was more advantageous for improving the respective value of $\mathrm{Tg}$ and specific volume, although disadvantageous in point of dimensional accuracy.

9) It was shown that the inner stresses were produced to a greater extent with the heat curing type resins than the self curing ones.

\section{緒賈}

アクリリック・レジンが1936年にドイッで "Paladon" という商品名で菊科界に紹介されて以来, 40 年以上経過 している.わが国では大阪工業試験所の大田がメタアク リル酸樹脂を紹介し，山本，永井（1941）'１，宮津らに よって改良が加えられ，現在菊科臨床に普及している。 アクリリック・レジンは操作性と番美性に優れ，口腔内 で比較的安定しており, 物理的性質も臨床的には満足し うるものであるために歯科臨床では重要な役割を演じて いる. しかし開発当初から指摘されているように，重合 時に収縮及び変形があるとと, 重合後の寸法変化が大き いてと，金属に比へて機械的強度が劣ることなどの久点 がある、そてでより理想的な材料にするためにアクリり ック・レシシンの質的改良を求めて研究がなされてきた。 例えば加熱操作をしないで重合させる self curing resin の開発 ${ }^{21}$ ， 常温重合開始剤である第 3 級アミンの 改良, 及び他の重合開始剂の開発 ${ }^{31}$, 架橋凪の添加, 加 圧形成法における埋没方法の考虑4-6)，加圧形成方式に かわるまのとしての流し込み方式の試行 ${ }^{7,8)}$, 流し込み 方式の加圧重合法 $\left.{ }^{1}, 10\right)$ や，石てう core 法などである.

self curing resin は加熱操作をしないために, 加熱 重合型レジンよりも温度変化が少なく，しかもガラス転 移温度付近の温度変化を受けないために重合時の変形が 小さいことや11-13'，W.L. McCracken (1953) ${ }^{14}$ ', F.E.Jeffreys $(1950)^{15)}$, J.W.Stanford $(1955)^{16}$, , G. M. Brauer（1959）17） らが報告しているように加熱 重合型レジンに比べて精度が良く，操作が簡単であるて となど種々の長所があるにもかかわらず，機械的強度が
加熱重合型レジンよりも劣っているととや，重合開始剤 として使用されている第 3 級アミンが変色の原因になる ことなどの理由によりあまり使用されなかった・しかし， J. B. Woelfel, F. F. Peyton (1963) ${ }^{181}$, W. E. Mowery（1958) 19) らは self curing resin で作製し た義菌も加熱重合型レジンで作製した義歯と同様，臨床 的には満足しうる機械的強さを有するものであると報告 している．また架橋剤の添加，改良201もされている し，更に第 3 級アミンの改良及び他の重合開始㓮の開発 により変色しにくくなったともいわれており， self curing resin の見なおしがされてきている.

また，従来の加熱重合型レジンは機械的性質が優れて いるにもかかわらず，重合時の操作が複雑であるために 加熱重合型レシシンと同程度の性能を有し，しかも加熱重 合操作を少しでも簡単にかつ能率よく行うことのできる レシシとして heat shock resin が開発された21,22).

さらに1967年, S. Winkler, W.L. Shepard らに よって埋没重合方法を全く変えた流し込みレジンが開発 されたが，このレジンはポリマーに対するモノマー量 が多いためにキャストしやすいとと，広義の意味での self curing resin であるために寸法精度が高いてと， 技工操作が簡単なととなどの長所をもっている．その反 面，機械的強さが加熱重合型レジンより劣ること，人工 霜が重合中に移動すること, 咬合高径が減少すること, レジン歯と床との接着がやや不確実なととなどの短所が 指摘されている．そこで，急激な重合熱の発生を抑える ことができ，重合熱を約 $80^{\circ} \mathrm{C}$ 亿保ち，重合時の気泡の 発生を抑制することができる加圧重合法の考案，ならび 
に人工歯の移動が少なく，咬合高径の変化が少ないなど の利点をもつ石こう core 法の考案がなされた.

以上の上うに各種タイプのレジンの開発及び改良がな されてきたが，各種レジン相互間の比較検討は十分にな されていない，そてで今回，レジンの種類及び埋没術式 の差による重合時内部応力の違いを比較するために, 予 備実験として strain gage 法と差動トランス法を用い て内部応力の発生の可能性を見出し, 次に比容積及びガ ラス転移温度の測定, 分子量の検討, 寸法安定性試験, 適合性試験を行って興味ある知見を得たので報告す ろ.

\section{予備 実 联}

本実験に入る前に self curing resinにより, strain gage 法と差動トランス法を用いて，レジン重合時にお ける内部応力発生の可能性について検討した。

\section{A. 予備実験の材料}

self curing resin として G-C 社製 Repairsin と 松風社製 Cast Resin t用いた．液/粉比は Repairsin が $\mathrm{M} / \mathrm{P}=5 / 10$ のものと $\mathrm{M} / \mathrm{P}=6 / 10$ のものの 2 種類, Cast Resin については $\mathrm{M} / \mathrm{P}=8 / 14$ のものと $\mathrm{M} / \mathrm{P}=$ 10/14のものの 2 種類とした.

\section{B . 予備実験の方法}

1. strain gage 法による実験

$0.3 \mathrm{~mm}$ の厚さのゲージ鋼の表面中央部に共和電業製 KFC-2-C1-11L300型 strain gage を設置し, 同時に 銅一コンスタンタン熱電対を鏝着したものを用意し，そ の反対面に幅 $10 \mathrm{~mm}$, 長さ $25 \mathrm{~mm}$, 厚み $2 \mathrm{~mm}$ の試料を 粉液混和直後に載せて $25 \pm 0.5^{\circ} \mathrm{C}$ の環境下におき，レシ ン重合時に扔こるゲージ鋼の変形を strain gageによ ってとらえ，ニコン工業株式会社製 Multipurpose Polygraph で増幅し，松下通信工業株式会社製 VP6541A型 2 ペンレコーダにて記録させた。なお，ゲー ジ鋼とレジンの接着が十分でないので，ゲージ鋼の両端 にそれぞれ直径 $1 \mathrm{~mm}$ の空をあけ維持孔とした。

strain gage を用いる場合には，ダミー・ゲージを用 いるべきであるが，本実験においててはダミー・ゲージを 設定することができなかったので，便宜的に銅一コンス タンタン熱電対によりレジン重合時に発生する重合熱の 熱信号を 2 ペンレコーダに記録させ，後でゲージ鋼の歪 量から重合熱分の信号量を引いてレジン重合時に発生す るレシンンの変形に伴うゲージ鋼の歪の補正を行った。

2. 差動トランス法による実験
レジン重合時のレシン自体の変形量を知るために, 粉 液混和直後に厚さ $2 \mathrm{~mm}$ になるように試料をとり, 差動 トランスによりレジンの変形量を実測した (Figs. 1〜 $3)$.

\section{C. 予備実験の結果}

strain gage 法による実験では測定值から重合時に発 生する重合熱分の信号量だけ, グラフ上で差し引いた補 正グラフを書いている.

差動トランス法による実験では，レジンの重合時の収 縮量を実測したが，ての值を試料の厚さで割り，歪とし てあらわしている.

Repairsin では差動トランス法と strain gage 法の 歪の発生はほぼ同時で,液/粉比が5/10のもので約 4.3 分 後, 6/10のもので約5.4分後となっており,ポリマーに対 するモノマー量が多くなると歪の発生は遅れている。ま た差動トランス法では液/粉比が $6 / 100$ 場合は約 8 分後 でほぼ安定した歪になっているのに対し, strain gage 法では約 8 分後から歪が急速度で増加し始めており, こ

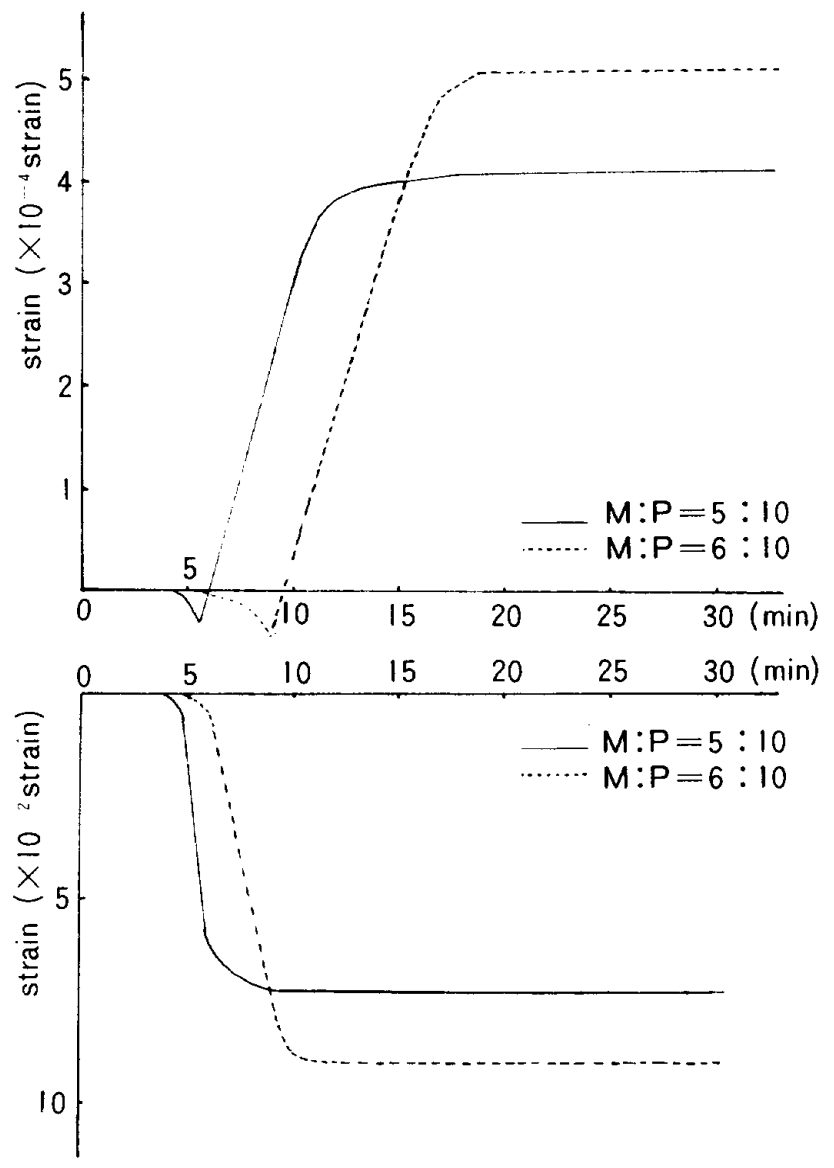

Fig. 1 Variation of strain measured by strain gage (upper) and strain transducer (lower) with time of Repairsin 


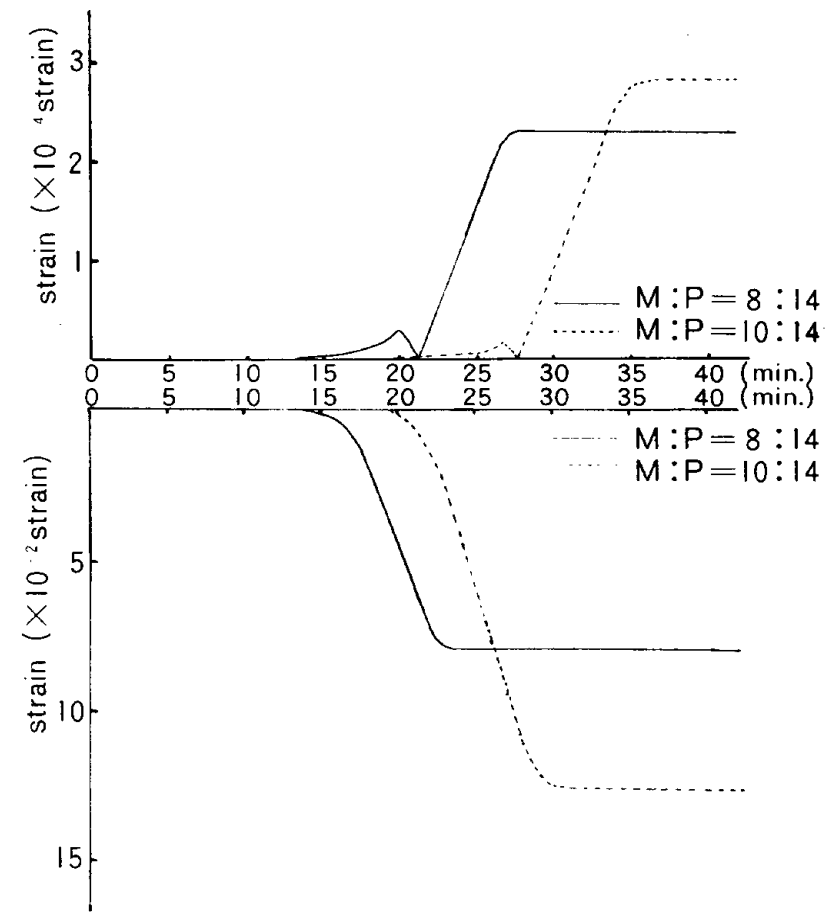

Fig. 2 Variation of strain measured by strain gage (upper) and strain transducer(lower) with time of Cast Resin

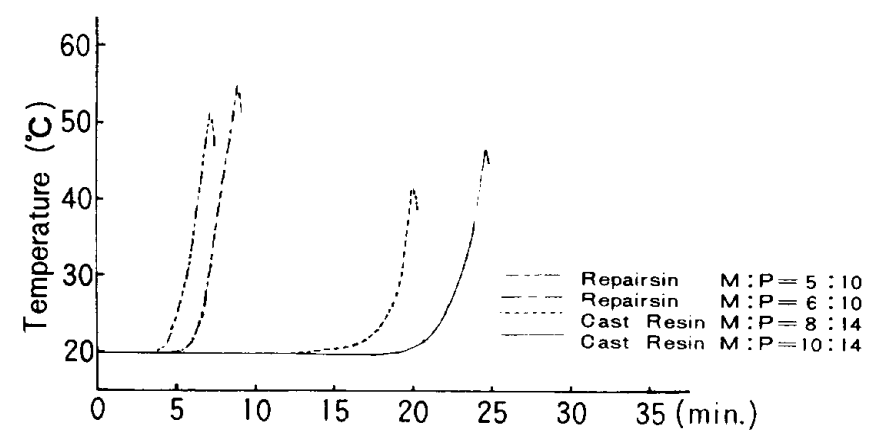

Fig. 3 Variation of temperature of curing process with time of Repairsin and Cast Resin
れが安定して最大值になるのは約13分後である、液/粉 比が5/10の場合は差動トランス法では約 7 分後に歪量は 安定状態になるが，そのときになってはじめて strain gage 法の歪が急速に発生しはじめている.

また, 雨量は液/粉比が $6 / 100$ とき差動トランス法で $\left(9.0 \pm 0.3 \times 10^{-2}\right)$, strain gage 法で $(5.1 \pm 0.3 \times$ $\left.10^{-4}\right)$, 液/粉比が5/10のとき差動トランス法で $(6.9 \pm$ $\left.0.2 \times 10^{-2}\right)$, strain gage 法で $\left(4.2 \pm 0.3 \times 10^{-4}\right)$ とな っており液/粉比を大きくすると奀量は増加している.

Cast Resin でも同様の傾向があり, 歪の発生時期は 液/粉比が同じであれば strain gage 法も差動トラン ス法もほぼ同時であり，てれは液/粉比を大きくすると 遅れる.すなわち液/粉比が 8/14のとき, strain gage 法, 差動卜ランス法とも歪発生時期は13.5分後であるの に対し，液/粉比が 10/14のときは，18～19分後となっ ている. 液/粉比が 8/14の場合の差動トランス法の歪 安定期は 䄪21分後であるが，乙のとき strain gage 法 の歪が急速に発生しはじめ, 安定期は約24分後である.

一方液/粉比が 10/14 の場合は差動トランス法での歪安 定期は約27分後であるが，乙れとほぼ同時に strain gage 法の歪が急速に増加し，安定期は 約 32 分 後であ る. 歪量は液/粉比が 8/14のとき差動トラスト法で $\left(8.1 \pm 0.2 \times 10^{-2}\right)$, strain gage 法で $(2.3 \pm 0.3 \times$ $\left.10^{-4}\right)$, 液/粉比が $10 / 14$ のき差動トランス法で（12.7 $\left.\pm 0.7 \times 10^{-2}\right)$, strain gage 法で $\left(2.8 \pm 0.1 \times 10^{-4}\right)$ と なっており液/粉比を大きくすると歪量は増加している

(Tables 1, 2).

Repairsin, Cast Resin とも重合熱の発生と歪発生 の時期は同時であるが重合熱のピークが出てから strain gage の症が急速に発生増加している.

\section{D. 予備実験の考察}

以上の結果からレジン重合時にはレジンは収縮をお こすが，乙の収縮が奶げられると内部応力が発生する。

Table 1 - Variation of strain measured by strain gage method with mixing ratio (M/P)

\begin{tabular}{|c|c|c|c|c|c|c|c|c|}
\hline & mono & $\begin{array}{r}\text { ymer } \\
(\mathrm{g})\end{array}$ & star & of & $\begin{array}{l}\text { rain } \\
\text { (min.) }\end{array}$ & $\begin{array}{r}\operatorname{maxi1} \\
(\times 1\end{array}$ & ${ }_{4}^{4} \mathrm{~s}$ & $\begin{array}{l}\text { strain } \\
\text { ain) }\end{array}$ \\
\hline \multirow{2}{*}{ Repairsin } & 5 & 10 & 4.3 & \pm & 0.3 & 4.2 & \pm & 0.3 \\
\hline & 6 & 10 & 5.4 & \pm & 0.4 & 5.1 & $\perp$ & 0.3 \\
\hline \multirow{2}{*}{ Cast Resin } & 8 & 14 & 13.5 & \pm & 0.7 & 2.3 & \pm & 0.3 \\
\hline & 10 & 14 & 19.2 & \pm & 0.9 & 2.8 & \pm & 0.1 \\
\hline
\end{tabular}


Table 2 - Variation of strain measured by strain transducer method with mixing ratio (M/P)

\begin{tabular}{|c|c|c|c|c|c|c|c|}
\hline & $\begin{array}{r}\text { monome } \\
(\mathbf{c c})\end{array}$ & $\begin{array}{r}\mathrm{r}: \text { polymer } \\
(\mathrm{g})\end{array}$ & start of & $\begin{array}{l}\text { train } \\
(\min .)\end{array}$ & $\begin{array}{r}\operatorname{maxir} \\
\langle\times 1\end{array}$ & & $\begin{array}{l}\text { strain } \\
\text { ain) }\end{array}$ \\
\hline \multirow{2}{*}{ Repairsin } & 5 & 10 & $4.3 \pm$ & 0.3 & 6.9 & $!$ & 0.2 \\
\hline & 6 & 10 & $5.4 \pm$ & 0.7 & 9.0 & \pm & 0.3 \\
\hline \multirow{2}{*}{ Cast Resin } & 8 & 14 & $13.5 \pm$ & 0.5 & 8.1 & \pm & 0.2 \\
\hline & 10 & 14 & $18.3 \pm$ & 0.6 & 12.7 & \pm & 0.7 \\
\hline
\end{tabular}

歪の発生は重合熱の発生とほぼ同時であるが，差動トラ ンス法における歪がはぼ安定状態になって，しかも重合 熱がピークに達した直後に strain gage 法の歪が急速に 増加することがわかった。つまり内部応力の発生はレジ ンが流動性のある間は非常に少ないが，発生した内部応 力が残留応力として残るのは，ある程度レジンが rigid になってからである．液/粉比が大きくなると歪の発生 時期は遅れ，焉量は大きくなる。これらのととを参考に して次のような本実験を行った。

\section{実験材料並びに試料作製方法}

\section{A. 実 験 材 料}

heat curing resin は $\mathrm{G}-\mathrm{C}$ 社製 Acron, heat shock resin は松風社製 $Q F$, self curing resinは G-C 社製 Repairsin, pour resin (広義の self curing resin）は松風社製Cast Resinを用いた．液/粉 比は使用説明書の指示に従った。

B. 埋 没方 法

Acron, QF, Repairsin に関しては, (i) G-C 社製硬石こう Plastone 単味で埋没したもの (plaster core type）と（ii)下盒は $\mathrm{G}-\mathrm{C}$ 社製硬石こう Plastone で埋没し，上盒は工業用シリコーンの東レーシリコーン SH-9555で2〜 3 mmの愿さだけ原型をコーティングし た後 Plastone で埋没したもの (Layered silicone rubber mold technique-silicone core type) 2 種類とした（Fig. 4 ).

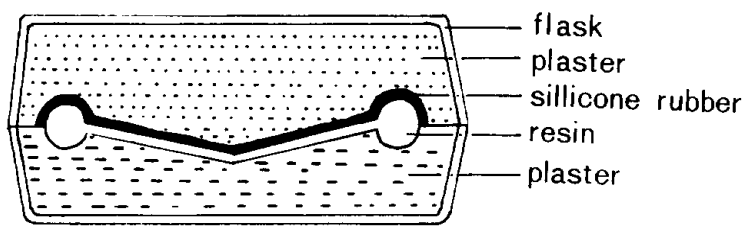

Fig. 4 Diagramatic representation of silicone core method
Cast Resin では，通法に従って Plastone と松風社 製 Cast Gel で埋没した ${ }^{23)}$ ．スプルーは重合体の収縮 に及ばす影響が最も少ないと思われる肉厚部に板状スプ ルーをたてた24-26)。

\section{C. 重 合 方 法}

Acron はモリタ製 Curing Unit（Fig.5）を用いて $60^{\circ} \mathrm{C}$ で 60 分間熬留後, 沸騰水中に60分間繫留して重合 を完結させ，室温まで空中放置して徐冷した。

QF は沸騰水中で10分間 繫留して重合を完結させた 後, 室温になるまで空中放置した。

Repairsin は室温で重合させた。

Cast Resin は（i)レジン注入後30分間空中放置し, 松風社製 Cast Rein 用重合槽を用いて $50^{\circ} \mathrm{C}$ で 30分間 重合させたもの (Cast Resin normal type) と（ii)

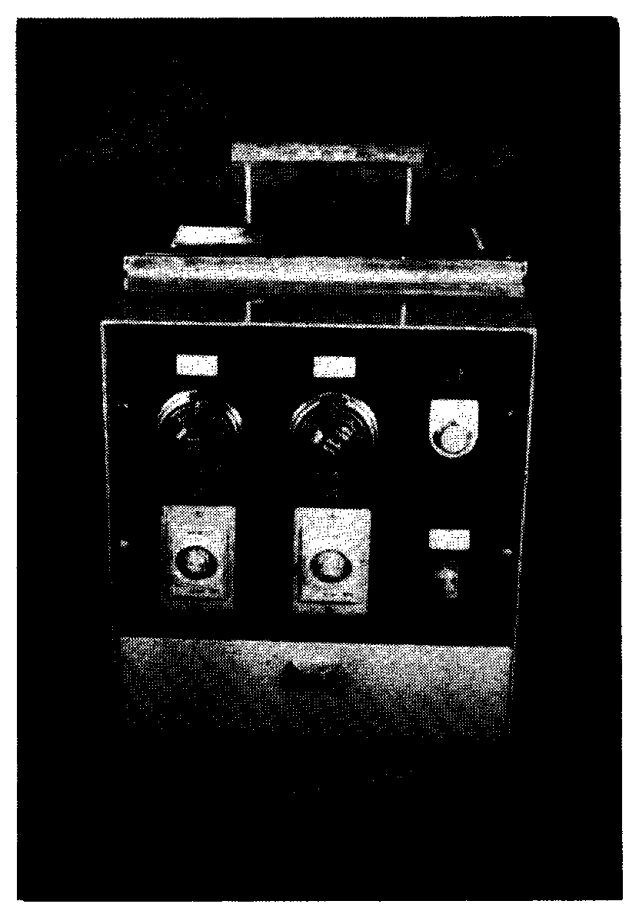

Fig. 5 J.M Curing Unit Model NC-1 


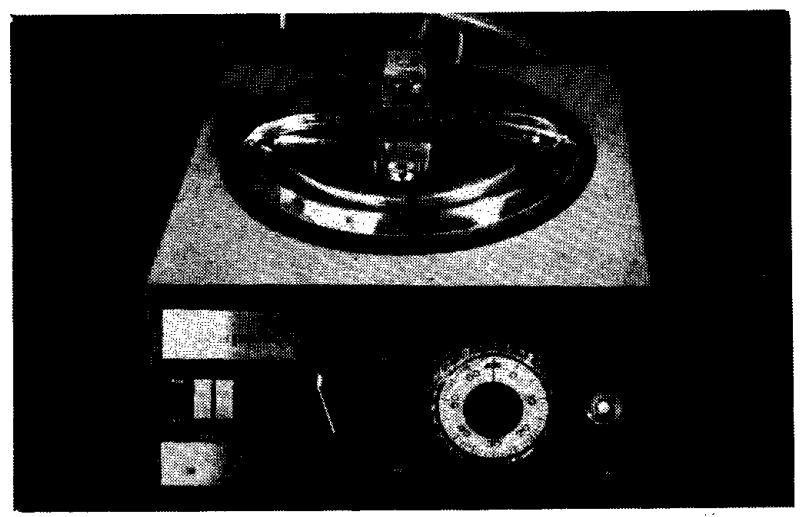

Fig. 6 Palamatic Practic

レジン注入直後に Kulzer 社製 Palamatic Plactic (Fig.6) に入れ，2.5気圧， $25^{\circ} \mathrm{C}$ の環境下で 30 分間 踒留して，その後に2.5気压, $45^{\circ} \mathrm{C}$ 環境下で30分間熬 留して重合を完結させたもの Cast Resin 加圧 type の 2 種類とした. 両者とも空中放置して室温まで徐冷し た.

\section{実 験 方 法}

A ．比䘱積及びガラス転移温度の測定 ${ }^{27-29 !}$

1. 比容積の測定

レジン重合体から 約 $0.5 \mathrm{~g}$ の試片をとり，デシケータ の中に入れて五酸化リンで脱水し，恒量になって (1/10,000gのオーダ) から測定に供した.

まずディラトメータの試料ケースに試料を人れ，試料 楇辺を満たすに十分な水銀を水銀だめに人れて涪封し， ついで他端より真空ポンプで吸引する.十分に吸引して から全体を試料ケース側に傾けて，水銀が試料周辺に満 たされたことを確めて吸引を止める。キャピラリ一中の 水銀を径 $0.3 \mathrm{~mm}$ のエナメル線を用いて適当な高さに比 りとってからディラトメータの試料部をオイルバスに雨 人し， $0.5^{\circ} \mathrm{C} / \mathrm{min}$ の昇温速度で加熱し，水銀之試料の 膨張量をディラトメータの水銀柱の高さで $5^{\circ} \mathrm{C}$ 毎に中村 製作所製ピ力読取顕微鏡 PRM-3XYZ（Fig.7） を用 いて $1 / 100 \mathrm{~mm}$ のオーダまで測定した.

これで得られた值を次の計算式にょり比容積に換算し た。

$$
\begin{aligned}
& \nu_{\mathrm{T}}= \frac{\mathrm{V}_{20}}{\mathrm{~A}}+\frac{\mathrm{A}\left(\mathrm{H}_{\mathrm{T}}-\mathrm{H}_{20}\right)-\alpha_{\mathrm{Hg}} \cdot \mathrm{VHg}(\mathrm{T}-20)}{\mathrm{m}} \\
& \nu_{\mathrm{T}}: \text { 各温度における比容積 } \\
& \mathrm{V}_{20}: 20^{\circ} \mathrm{C} \text { におる試料の体積 }
\end{aligned}
$$

A : キャピラリーの断面積

$\mathrm{H}_{\mathrm{T}} ： \mathrm{~T}^{\circ} \mathrm{C}$ 亿おける水銀柱の高さ

$\mathrm{H}_{20}: 20^{\circ} \mathrm{C}$ における水銀柱の高さ

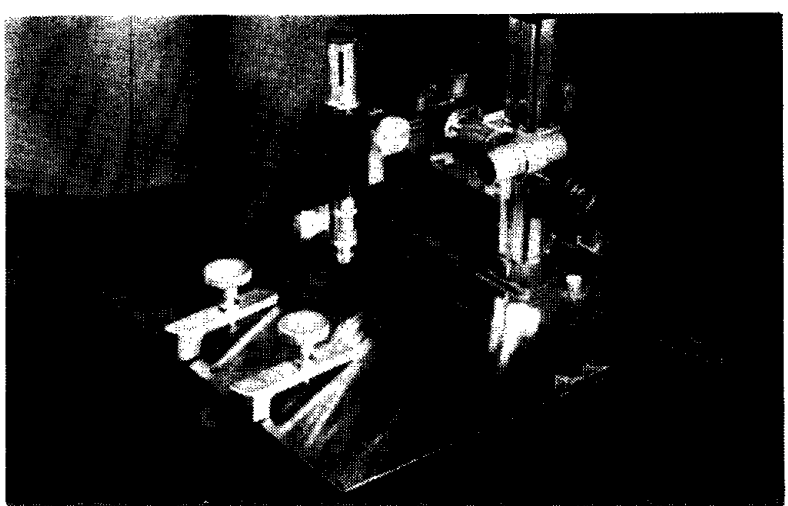

Fig. 7 Measuring Microscope PRM-3XYZ

$$
\begin{aligned}
& \alpha_{\mathrm{Hg}}: \mathrm{Hg} \text { の熱膨張率 } \\
& \mathrm{V}_{\mathrm{Hg}}: 20^{\circ} \mathrm{C} \text { における } \mathrm{Hg} \text { の体積 } \\
& \mathrm{m} \quad: \text { 試料の重量 }
\end{aligned}
$$

なお笑験に用いたディラトメータは九州歯科大学理工 学教室において作製されたものである（Fig.8）。

\section{2. ガラス転移温度の測定}

線状高分子を加熱していくと徐々に軟化し，ガラス転 移温度に達すると急に軟化度が上昇する.したがってガ ラス転移温度付近に扔いて膨張係数及び硬さなどの諸物 性が急激に変化する.そこで比容積の測定で得られた值 から横軸に温度, 縦軸に比容積をとり, 比容積一温度曲 線を求め, 乙の比容積一温度曲線の低温部における接線 と,ガラス転移温度より十分に高温と思われる高温部で

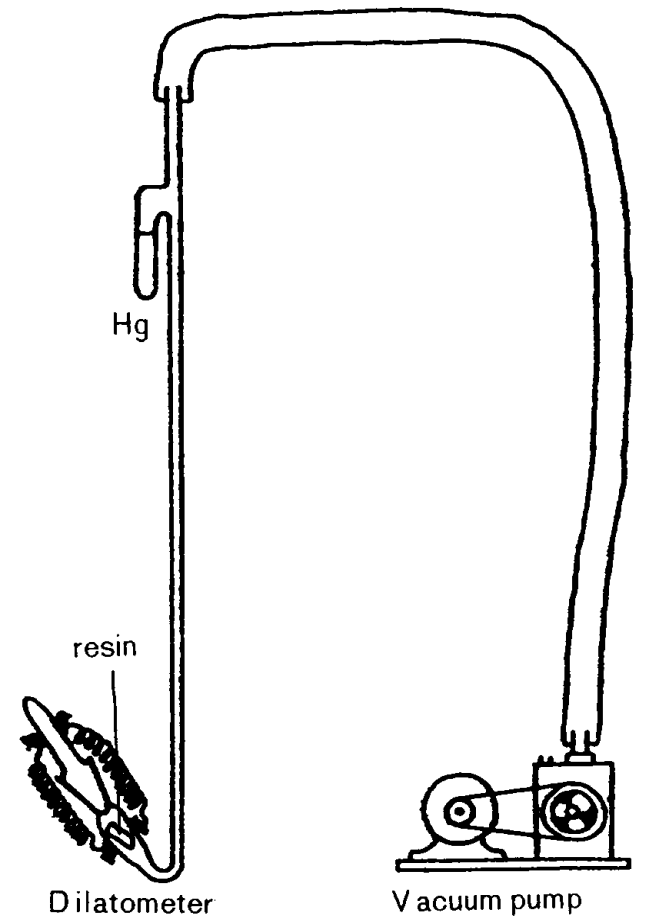

Fig. 8 Schematic diagram of Dilatometer 
の接線との交点をガラス転移温度（Tg）と定めた。

B. 分子量 ${ }^{30-32}$ )

高分子材料の物理的性質はその分子量の大きさによっ て影響を受ける・したがって平均分子量や分子量分布を 正確に調べることによって，その材料の物理的性質をあ る程度説明することができる。

分子量の測定法には粘度法, 是透圧法, 我点降下法, 屈折率法などがあるが，測定が比較的簡単で精度も高い と思われる粘度法によった。まず高分子稀釉溶液を作る ために各レジン重合体から $0.1 \mathrm{~g} ， 0.2 \mathrm{~g}, 0.3 \mathrm{~g}, 0.4$ $\mathrm{g}, 0.5 \mathrm{~g}$ だけ正確にとり，乙の試料をメスコルベンに 入れ，有機溶剤を $100 \mathrm{cc}$ になるまで追加注入した，有機 溶剤としてはベンゼン, アセトン, クロロホルム, トル エンを用いた・なおこの操作はヤマト工業社製恒温水槽 内で $25 \pm 0.03^{\circ} \mathrm{C}$ 温度範囲内で行った。

\section{C. 寸法安定性試験}

義柬床用材料の寸法精度の良否は，その材料の臨床的 有用性をみるうえで 1 つの重要な要素である.そこでレ ジンの重合過程での重合収縮及び重合後の時間的経過に 伴う寸法変化を調べた。

すなわち $10 \times 50 \times 2 \mathrm{~mm}$ のんざく状試験片を作り， 離型直後， $1,2,3,4,5,6,7,8,9,10$, 15，20，30日後の14回にわたって中村製作所製ピ力読取 顕微鏡PRM-3XYZで 標点間距離を1/100mmの精度で 测定した。な㨐存条件は $20^{\circ} \mathrm{C}, 37^{\circ} \mathrm{C}, 50^{\circ} \mathrm{C} の 3$ 種 類の環境温度で, それぞれの温度について水中浸漬した 吸水試料と空中放置した乾燥試料を作製した。水中浸漬 用にはヤマト工業社製恒温水槽で $\pm 0.5^{\circ} \mathrm{C}$ の温度 環境 とし, 空中放置には中嶋理化学器械工業株式会社製電気 定温器を用いた。各条件について 5 個づつの試料を作製 して計測を行い，重合収縮率及び重合後の経時的変化な らびに変化の温度依存性について調べた。

D. 適合性試 験

Fig. 9 に示すような唇さ $2.5 \mathrm{~mm}$ の湓を模型化した

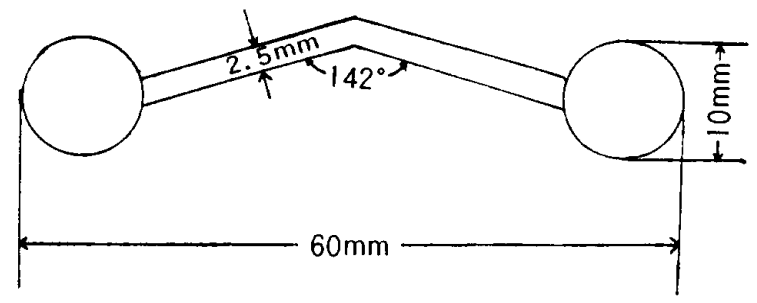

Fig. 9 Diagramatic representation of test specimen

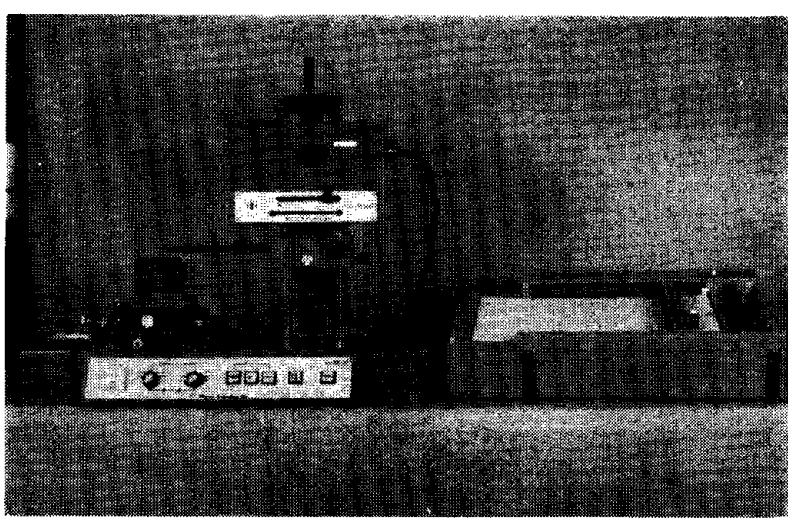

Fig.10 Test apparatus (SE-3C, WK 432)

山型金属原型を作製し，乙れによってレジン試片を作 り，小坂研究所製 $\mathrm{EF}$ F-1 型フォームコーダとそれに連 動する渡辺測器株式会社製WX432型X-Yレコーダに より記録させた（Fig.10）。試片の保存条件は $20^{\circ} \mathrm{C}$, $37^{\circ} \mathrm{C}, 50^{\circ} \mathrm{C}$ 環境温度とし，それぞれの温度について 水中浸漬した吸水試片と空中放置した乾燥試片を作製し た. 計測時点は離型直後, $1,2,3,4,5,6,7$, $8,9,10,15,20,30$ 日後の 14 回とし, 金属原型の 2 面がなす角度に対する変化率を計算し, 離開角の変化率 及びその温度依存性について調べた。

各条件について 5 個づつの試料を作り測定を行った。

\section{実 験 結 果}

\section{A. 比容積の測定}

Acron, QF, Repairsin, Cast Resinの比容積一温 度曲線をFigs. 11〜 14に示している. Acron の $20^{\circ} \mathrm{C}$ おける比容積はsilicone core typeが $(0.8200 \pm 0.0012)$ $\mathrm{cm}^{3} / \mathrm{g}$ で, plaster core type では $(0.8365 \pm 0.0021)$ $\mathrm{cm}^{3} / \mathrm{g}$ であり, silicone core type の方が plaster core type より小さい值であった.

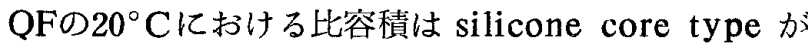
$0.8235 \pm 0.0015) \mathrm{cm}^{3} / \mathrm{g}$ で, plaster core type が $(0.8438 \pm 0.0020) \mathrm{cm}^{3} / \mathrm{g}$ であり, silicone core type の方が plaster core typeより小さい值であった。

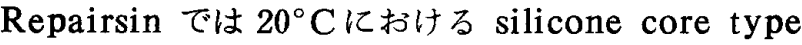
が $(0.8338 \pm 0.0023) \mathrm{cm}^{3} / \mathrm{g}$, plaster core type が $(0.8486 \pm 0.0025) \mathrm{cm}^{3} / \mathrm{g}$ であり, silicone core type の方が plaster core type より小さい值であった。

Cast Resin では normal type が $(0.8420 \pm 0.0018)$ $\mathrm{cm}^{3} / \mathrm{g}$ で, 加圧 type が $(0.8350 \pm 0.0014) \mathrm{cm}^{3} / \mathrm{g}$ であ り, normal type が加圧 type より大きい值であっ た。 


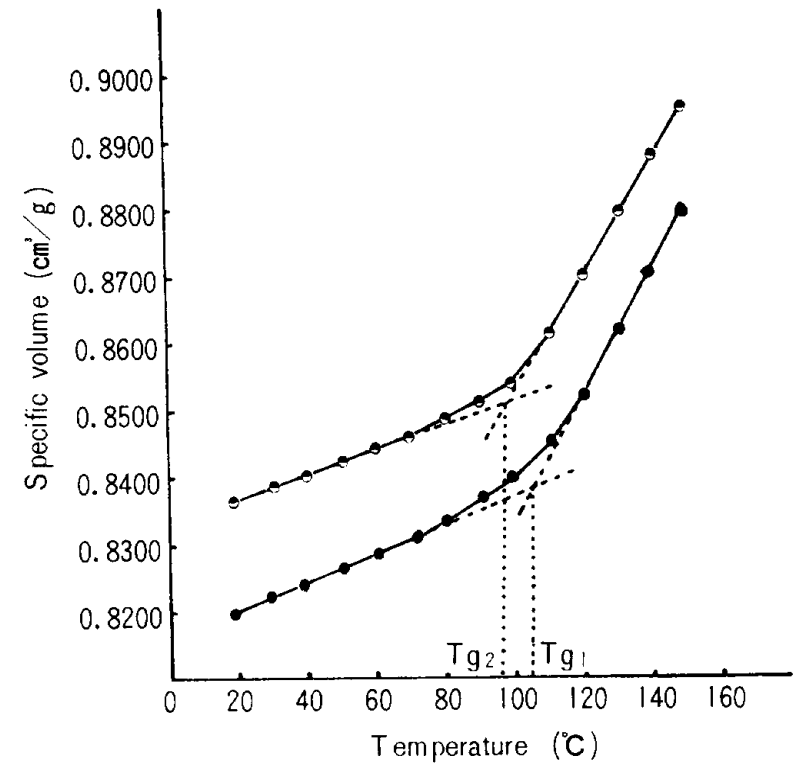

Fig.11 Variation of specific volume of Acron with temperature

- : silicone core type

- : plaster core type

$\mathrm{Tg}_{1}: \mathrm{Tg}$ of silicone core type $\mathrm{Tg}_{2}: \mathrm{Tg}$ of plaster core type

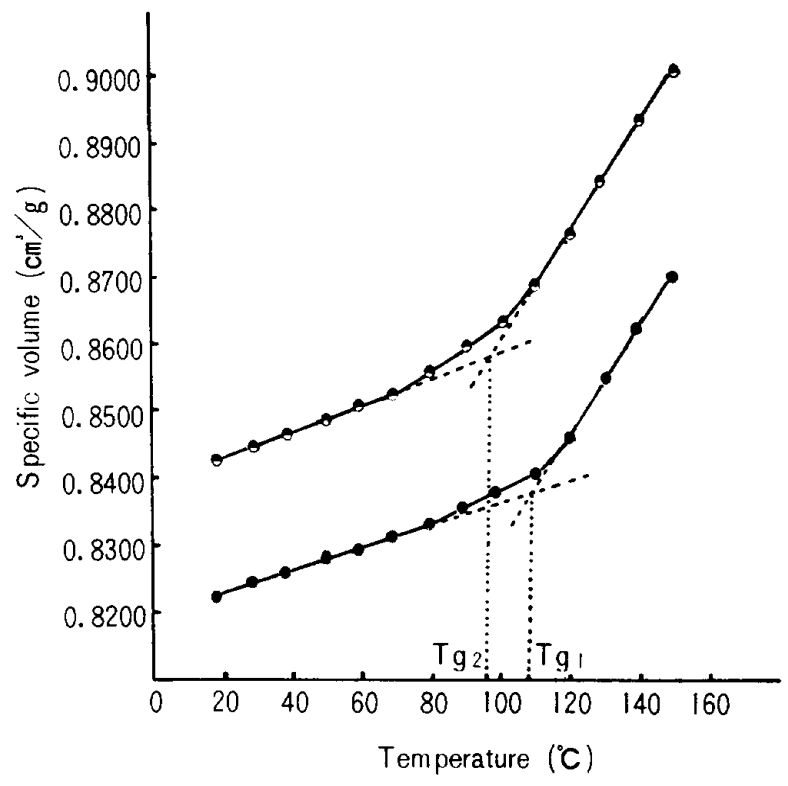

Fig.12 Variation of specific volume of $\mathrm{QF}$ with temperature

- : silicone core type

- : plaster core type

$\mathrm{Tg}_{1}: \mathrm{Tg}$ of silicone core type

$\mathrm{Tg}_{2}: \mathrm{Tg}$ of plaster core type

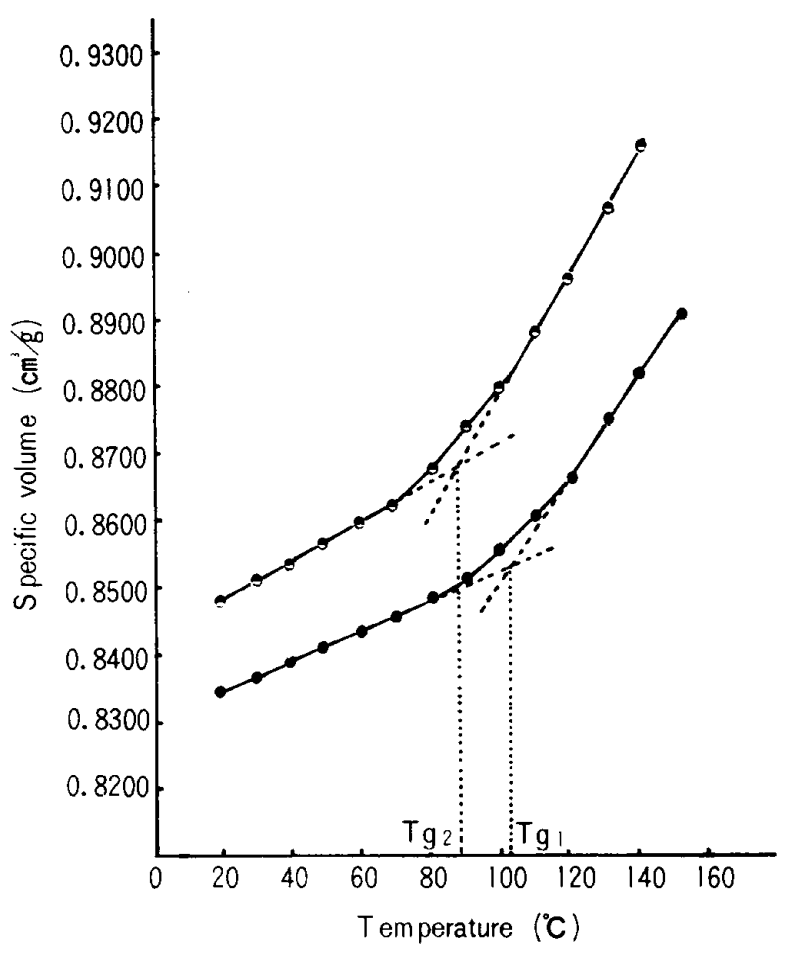

Fig.13 Variation of specific volume of Repairsin with temperature

- : silicone core type

- : plaster core type

$\mathrm{Tg}_{1}: \mathrm{Tg}$ of silicone core type

$\mathrm{Tg}_{2}: \mathrm{Tg}$ of plaster core type

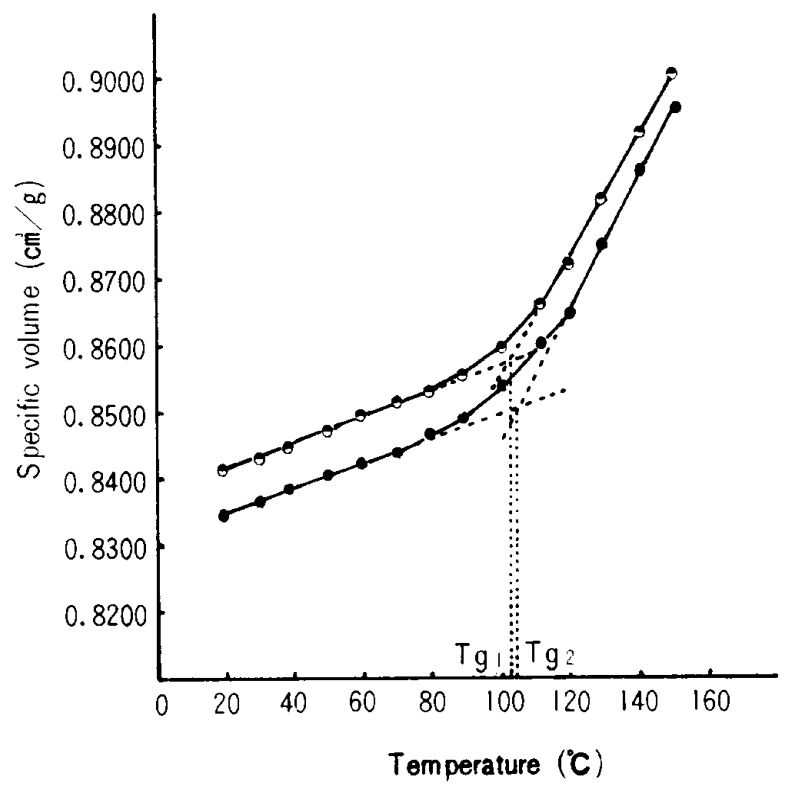

Fig.14 Variation of specific volume of Cast Resin with temperature

- : normal type

$\mathrm{Tg}_{1}: \mathrm{Tg}$ of normal type

$\mathrm{Tg}_{2}: \mathrm{Tg}$ of press type 
Table 3 - Glass transdition temperature $(\mathrm{Tg})$ of various $\operatorname{resins}\left({ }^{\circ} \mathrm{C}\right)$

\begin{tabular}{|c|c|c|c|c|c|c|c|c|}
\hline \multirow{3}{*}{$\mathrm{Tg}$} & \multicolumn{2}{|c|}{ Repairsin } & \multicolumn{2}{|c|}{ QF } & \multicolumn{2}{|c|}{ Acron } & \multicolumn{2}{|c|}{ Cast Resin } \\
\hline & $\begin{array}{l}\text { Plaster } \\
\text { core type }\end{array}$ & $\begin{array}{l}\text { Sillicone } \\
\text { core type }\end{array}$ & $\begin{array}{l}\text { Plaster } \\
\text { core type }\end{array}$ & $\begin{array}{l}\text { Sillicone } \\
\text { core type }\end{array}$ & $\begin{array}{l}\text { Plaster } \\
\text { core type }\end{array}$ & $\begin{array}{l}\text { Sillicone } \\
\text { core type }\end{array}$ & $\begin{array}{c}\text { Plaster }+ \\
\text { Cast Gel }\end{array}$ & Press type \\
\hline & $90 \ll$ & 102 & $96 \quad(<$ & 107 & $96<<$ & 105 & 103 & $\Rightarrow 104$ \\
\hline
\end{tabular}

加圧重合法を用いて重合するレジン間で比較すると silicone core type $920^{\circ} \mathrm{C}$ における比容積は, Acron $<\mathrm{QF}<$ Repairsin であり, plaster core type でも Acron $<\mathrm{QF}<$ Repairsin の順であった. Cast Resin の normal type は Repairsin の plaster core type とほぼ同じ值であるが, 加圧操作を行うと比容積は小さ くなった。

以上の数值は 5 回の測定結果の平均值である.

B. $\mathrm{Tg}$ の測定

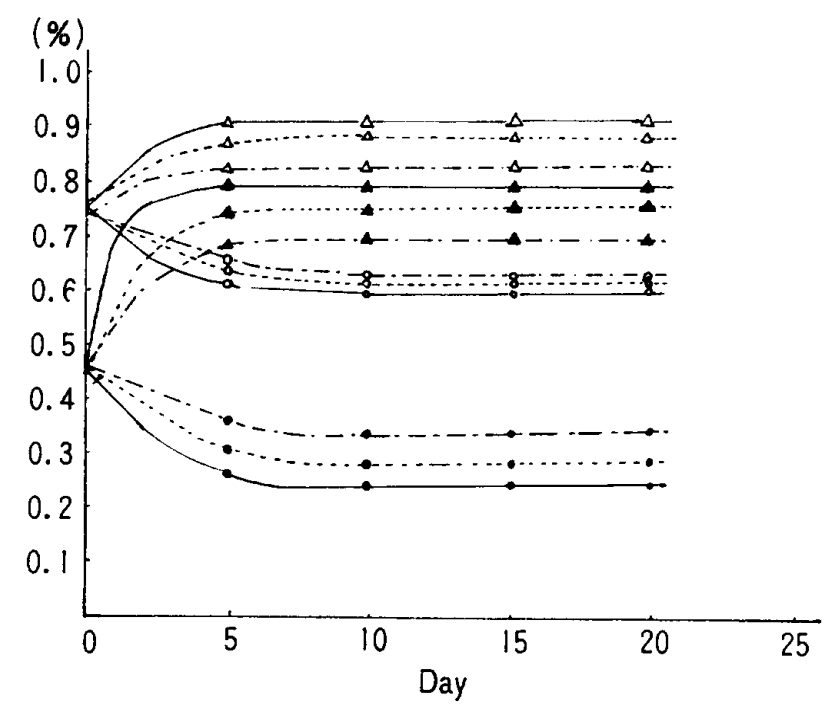

Fig.15 Dimensional changes of Acron after polymerization

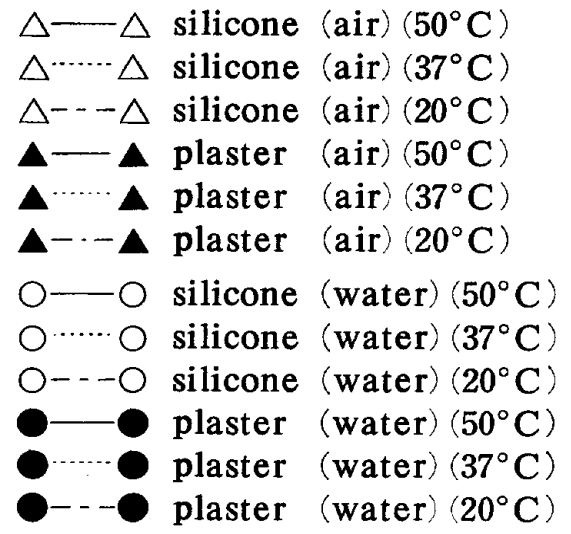

Figs.11〜14のグラフの低温部における接線と，Tgよ り十分高温部之思われる温度領域における接線の延長線 の交点を $\mathrm{Tg}$ として示している.

silicone core type と plaster core type の比較で は, Acron, QF, Repairsin とも silicone core type の方が plaster core type より高温で，その差はそれ ぞれ $9^{\circ} \mathrm{C}, 11^{\circ} \mathrm{C}, 12^{\circ} \mathrm{C}$ であった (Table 3).

各種レジン間で比較すると, silicone core type で は $\mathrm{QF}>$ Acron $>$ Repairsin であり, plaster core

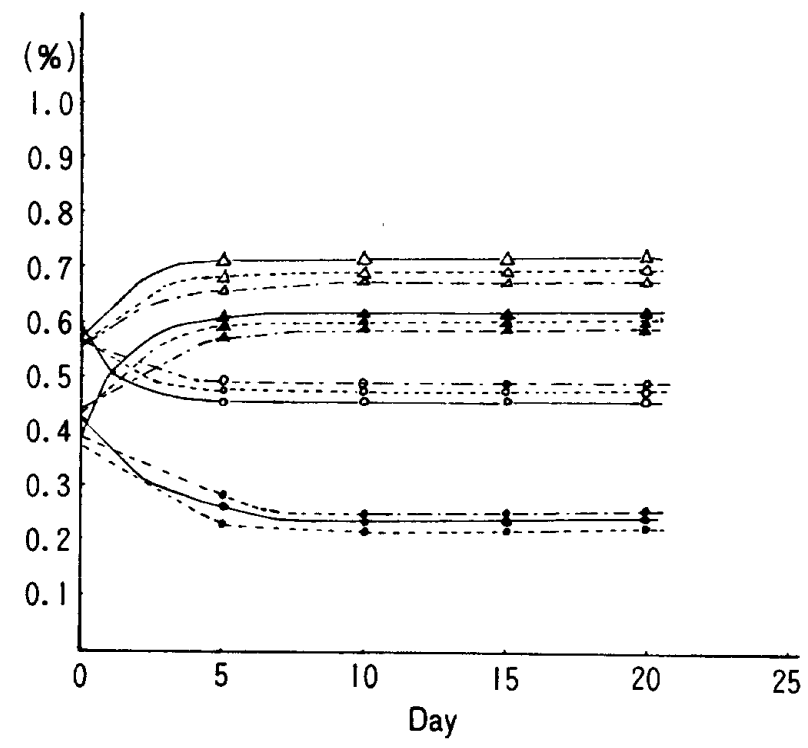

Fig.16 Dimensional changes of QF after polymerization
$\triangle \longrightarrow \triangle$ silicone (air) $\left(50^{\circ} \mathrm{C}\right)$
$\triangle \cdots \cdots \cdot \Delta$ silicone (air) $\left(37^{\circ} \mathrm{C}\right)$
$\triangle-\cdots-\triangle$ silicone (air) $\left(20^{\circ} \mathrm{C}\right)$
$\Delta$ - $\Delta$ plaster (air) $\left(50^{\circ} \mathrm{C}\right)$
$\Delta$ - plaster (air) $\left(37^{\circ} \mathrm{C}\right)$
$\Delta--\Delta$ plaster (air) $\left(20^{\circ} \mathrm{C}\right)$
$\mathrm{O}-\mathrm{O}$ silicone (water) $\left(50^{\circ} \mathrm{C}\right)$
O …... s silicone (water) $\left(37^{\circ} \mathrm{C}\right)$
$\mathrm{O}---\mathrm{O}$ silicone (water) $\left(20^{\circ} \mathrm{C}\right)$
- plaster (water) $\left(50^{\circ} \mathrm{C}\right.$ )
- plaster (water) $\left(37^{\circ} \mathrm{C}\right)$
plaster (water) $\left(20^{\circ} \mathrm{C}\right)$ 
type では $\mathrm{QF}=$ Acron $>$ Repairsin であった。

Cast Resin では重合法による差はほとんどなく， Acron, QF, Repairsin $の$ silicone core type ほぼ等しい值であった。

\section{C. 分子量}

逆流型キャノンフェンスケ毛管粘度計を用いて粘度平 均分子量の測定を試みた。

ベンゼン，アセトン，クロロホルム，トルエンの各浴 媒によって高分子稀釈溶液を作製しようとしたが，いず れの溶媒にもレジンは溶解せず分子量の決定はできなか った。このことは現在市販されているレジンが高密度の 架橋構造を呈していることを暗示していると思われる.

\section{D. 寸法安定性試験}

重合直後の収縮率は Acron の silicone core type で $(0.75 \pm 0.06) \%$, plaster core type で $(0.47 \pm$ $0.01) \%, \mathrm{QF} の$ silicone core type で $(0.57 \pm 0.02)$

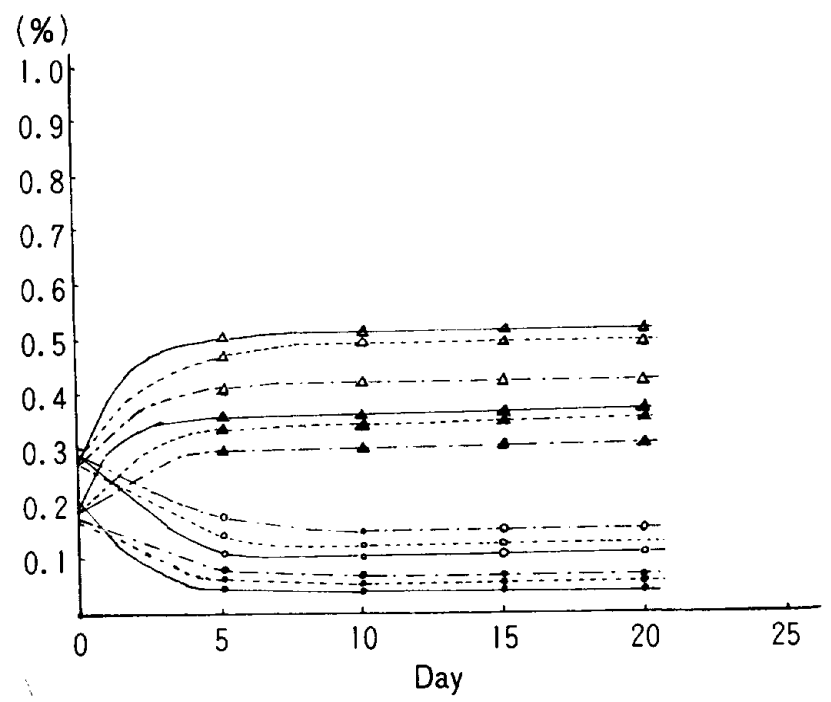

Fig.17 Dimensional changes of Repairsin after polymerization

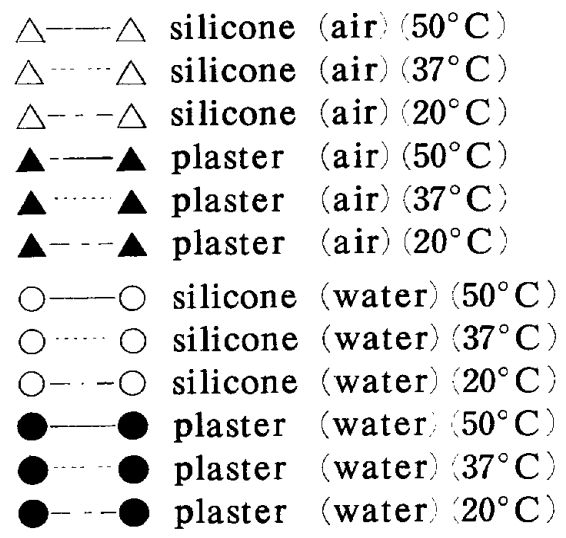

$\%$, plaster core type で $(0.42 \pm 0.02) \%$, Repairsin

の silicone core type で $(0.28 \pm 0.04) \%$, plaster core type で $(0.18 \pm 0.04 \%$, Cast Resin の加圧 type で $(0.19 \pm 0.02) \%$, normal type で $(0.34 \pm$ 0.05)\%の線収縮率を示した。

経時的変化はAcron, QF, Repairsin, Cast Resin の全試料に関して，吸水試料では膨張し，乾燥試料では 収縮する傾向にあるが, 重合時より約 7 日経過後は大体 安定していた（Figs. 15～18）.

\section{E. 適 合 性試 験}

レジン試片の離開角 $\theta$ を測定し, 金属原型の離開角 $\theta_{0}$ との差を $\theta_{0}$ で割ったもの $\theta_{0} \sim \theta / \theta_{0}$ を変化率 $\gamma$ とし， この変化率の経時的変化, 温度依存性について Figs.19 〜22に示している.

離型後の変化率は Acron の silicone core type で $1.40 \pm 0.06) \%$, plaster core type で $(1.03 \pm 0.10$

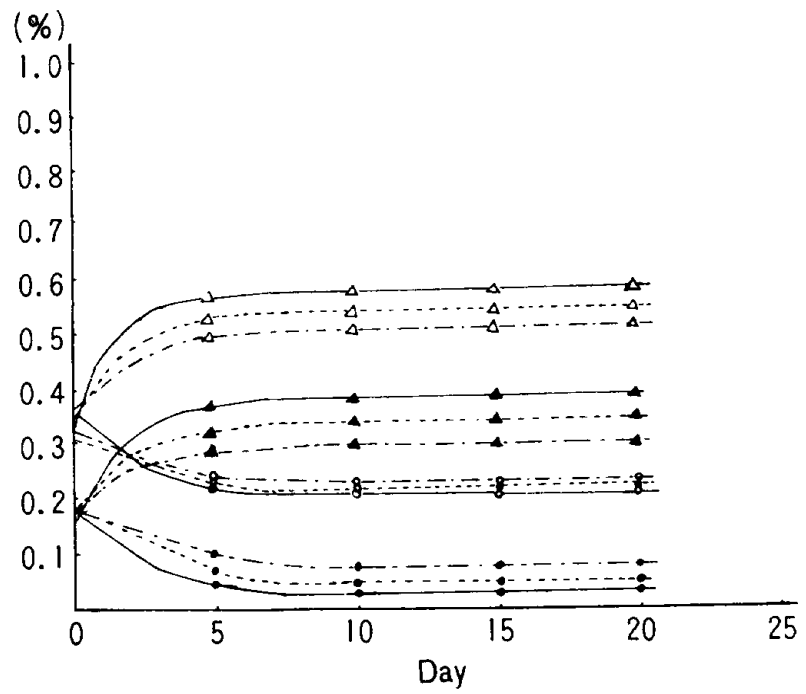

Fig.18 Dimensional changes of Cast Resin after polymerization

\begin{tabular}{|c|c|c|}
\hline$\triangle \longrightarrow \triangle$ & normal & (air) $\left(50^{\circ} \mathrm{C}\right)$ \\
\hline & normal & (air) $37^{\circ} \mathrm{C}$ ) \\
\hline & normal & (air) $\left(20^{\circ} \mathrm{C}\right)$ \\
\hline & press & (air) $\left(50^{\circ} \mathrm{C}\right)$ \\
\hline & press & (air) $\left(37^{\circ} \mathrm{C}\right)$ \\
\hline & press & (air) $\left(20^{\circ} \mathrm{C}\right)$ \\
\hline$-c$ & normal & (water) $\left(50^{\circ} \mathrm{C}\right)$ \\
\hline & normal & (water) $\left(37^{\circ} \mathrm{C}\right)$ \\
\hline & normal & $($ water $)\left(20^{\circ} \mathrm{C}\right)$ \\
\hline & press & (water) $\left(50^{\circ} \mathrm{C}\right)$ \\
\hline & & (water) $37^{\circ} \mathrm{C}$ ) \\
\hline & & (water) $20^{\circ} \mathrm{C}$ ) \\
\hline
\end{tabular}


$\%$, QF の silicone core type で $(1.32 \pm 0.04) \%$, plaster core type で $(0.63 \pm 0.08) \%$, Repairsin silicone core type で $(0.50 \pm 0.04 \%$, plaster core type で $(0.24 \pm 0.04) \%$, Cast Resin の加圧 type で $(0.39 \pm 0.05) \%$, normal type で $(0.72 \pm 0.03) \%$ であった。

重合後の変形は Acron, QF, Repairsin, Cast Resin の全てについて, 吸水試料ではやや変形率が減 少していたが乾燥試料ではやや増加しており, 離型後大 体 4 〜 日で安定状態に入っていた.

\section{考察}

\section{A. 比容積及び $\mathrm{Tg}$ の測定}

比容積はAcron, QF, Repairsin では silicone core type より plaster core type の方が大きく, Cast Resin では加圧 type より normal type の方が

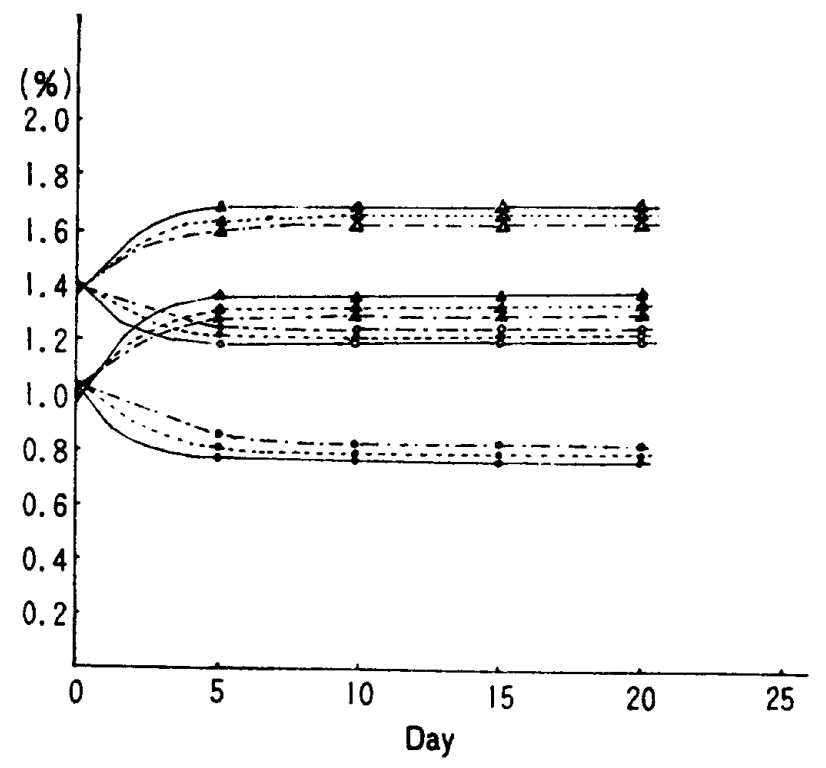

Fig.19 Variation rate of central angle with time of Acron

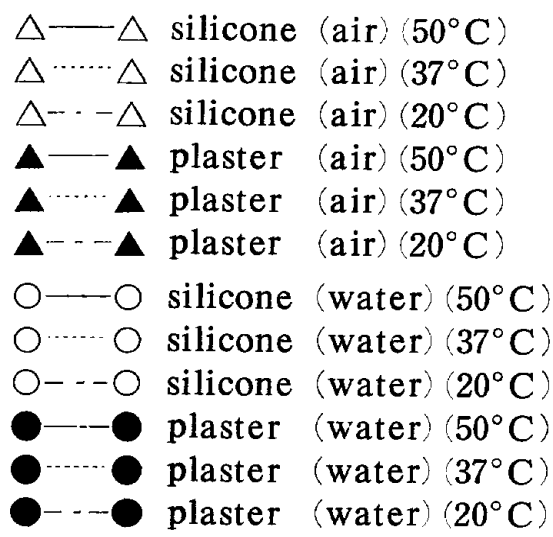

大きい值であった、一方，加圧重合法を用いて重合する 各種レジン間でみると silicone core type も plaster core type \& Acron $<\mathrm{QF}<$ Repairsin となってい た.

Tg は Acron, QF, Repairsin では plaster core type より silicone core type の方が高い值であるが Cast Resin では normal type と加圧 type は，ほぼ 等しい值となっていた。一方, 加圧重合法を用いて重合 する各種レジン間でみると silicone core type では QF $>$ Acron $>$ Repairsin であり, plaster core type では $\mathrm{QF}=$ Acron $>$ Repairsin であった.しかあ Repairsin では silicone core type における Tg が 非常に高くなって扔り，他の type のレジンの Tg に 近づいているのが注目される. Cast Resin では雨者の 差はあまりなく, Acron, QF の silicone core type の值に非常に近くなっていた。

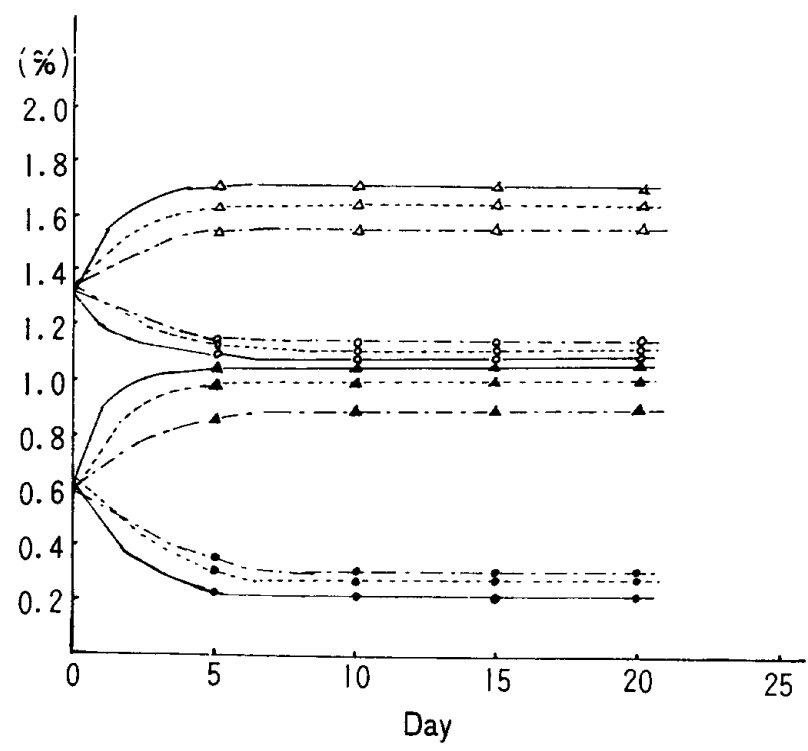

Fig.20 Variation rate of central angle with time of $\mathrm{QF}$
$\triangle-\triangle$ silicone (air) $\left(50^{\circ} \mathrm{C}\right)$
$\triangle \cdots \cdots$ silicone (air) $\left(37^{\circ} \mathrm{C}\right)$
$\triangle \cdots$ silicone (air) $\left(20^{\circ} \mathrm{C}\right)$
$\Delta$ - $\Delta$ plaster (air) $\left(50^{\circ} \mathrm{C}\right)$
A.... plaster (air) $\left(37^{\circ} \mathrm{C}\right)$
$\Delta---\Delta$ plaster (air) $\left(20^{\circ} \mathrm{C}\right)$
$\mathrm{O}-\mathrm{O}$ silicone (water) $\left(50^{\circ} \mathrm{C}\right)$
$\bigcirc \cdots$ silicone (water) $\left(37^{\circ} \mathrm{C}\right)$
$\mathrm{O}^{--}-\mathrm{O}$ silicone (water) $\left(20^{\circ} \mathrm{C}\right)$
plaster (water) $\left(50^{\circ} \mathrm{C}\right.$ )
- plaster (water) $\left(37^{\circ} \mathrm{C}\right.$ )
plaster (water) $\left(20^{\circ} \mathrm{C}\right.$ ) 
これらは Acron, QF, Repairsin の dough(餅状 物）の状態に影響されるものと思われる。つまり， dough の状態では粘着性が大であるために，石てう型 に入れた場合は们うとレジンが接着し，重合の過程で porous な重合体が得られるのに対し, silicone core typeでは silicone に対する resin の接着性が低いた めに一層密な重合体が得られることになる。これが比容 積の差になっており，Tgの差の一母とも考えられる。 例えば dough の状態で最も粘着性の高い Repairsin の plaster core type の $\mathrm{Tg} は 90^{\circ} \mathrm{C}$ で, Acron, $\mathrm{QF} 996^{\circ} \mathrm{C}$ に比べ非常に低く，しかも比容積は（0.8486 $\pm 0.0025) \mathrm{cm}^{3} / \mathrm{g}$ であって他の type のものより著しく 大きい值を示していた。一方, silicone core type では $\mathrm{Tg}$, 比容積とも他の type のレジンに近づいてい た。

\section{B . 寸法安定性試験}

重合直後の収縮率を比較すると, 加熱重合法を用いる

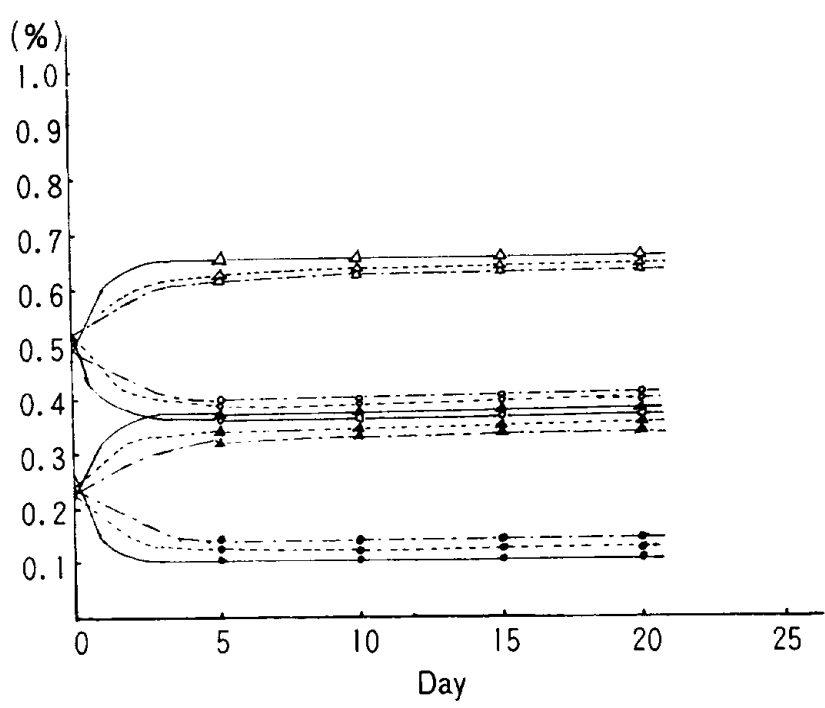

Fig.21 Variation rate of central angle with time of Repairsin

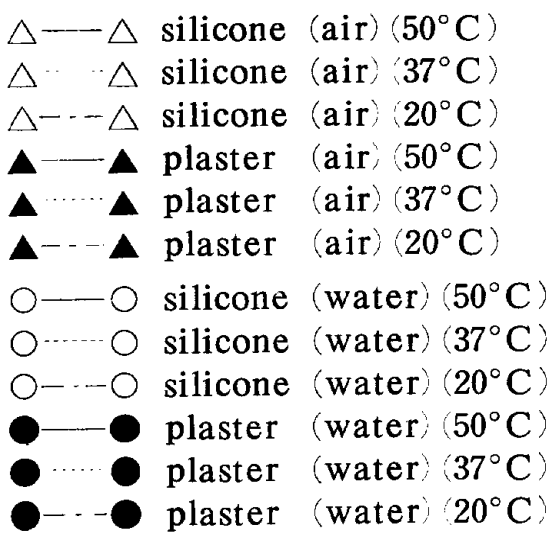

レジンである Acron, QF の plaster core type では それぞれ $(0.47 \pm 0.01) \% ，(0.42 \pm 0.02) \%$ であが self curing resin である Repairsin 及び self curing resin の一種とみなされる Cast Resin ではそれぞれ $(0.18 \pm 0.04) \%, \quad(0.34 \pm 0.05) \%$ \%あった。また silicone core type では Acron, QFがそれぞれ 0.75 $\pm 0.06) \% ，(0.57 \pm 0.02) \%$ であったのに対し， self curing type resin では Repairsin で $(0.28 \pm 0.04)$ \%であり, Cast Resin の加圧 type で $(0.19 \pm 0.02) \%$ であった.つまり silicone core type, plaster core type とも加熱重合型レジンに対して self curing type resin は, 約 1/3〜1/2 という著しく小さい值であった。 これを統計的にみると加熱重合法を用いる resin curing type resin䦐の重合直後の収縮率には高度に有 意の差があった，加熱重合法を用いるレジンより self curing type resin の方が収縮率が小さいのは，E.W. Skinner $(1960)^{33}$, W.E.Mowery (1958) らがいっ

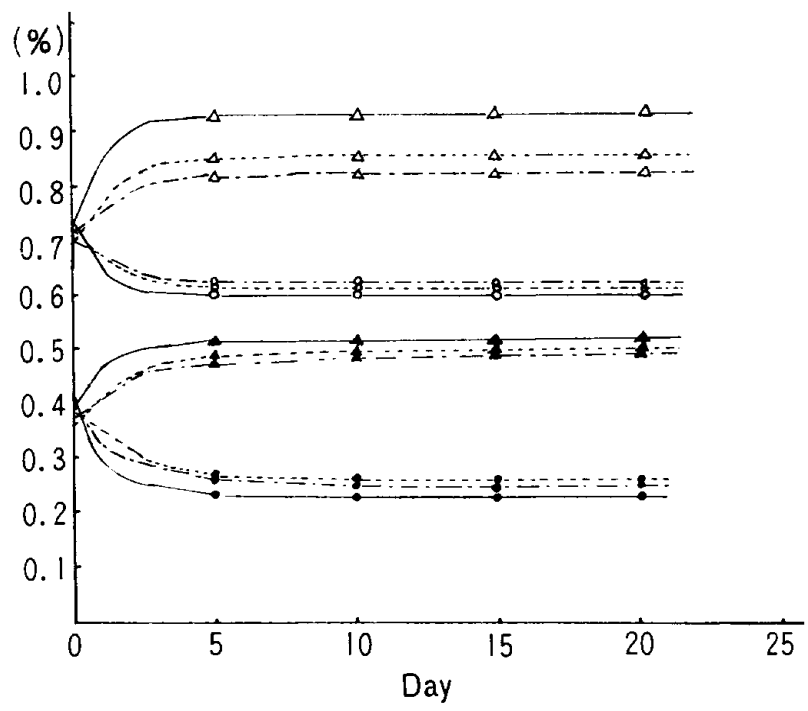

Fig.22 Variation rate of central angle with time of Cast Resin

\begin{tabular}{|c|c|c|}
\hline$\Delta-$ & normal & (air) $\left(50^{\circ} \mathrm{C}\right)$ \\
\hline & normal & (air) $\left.37^{\circ} \mathrm{C}\right)$ \\
\hline & normal & (air) $\left(20^{\circ} \mathrm{C}\right)$ \\
\hline $\mathbf{A}$ & press & (air) $50^{\circ} \mathrm{C}$ ) \\
\hline & press & (air) $\left(37^{\circ} \mathrm{C}\right)$ \\
\hline & press & (air) $\left(20^{\circ} \mathrm{C}\right)$ \\
\hline 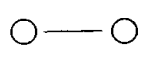 & normal & $($ water $)\left(50^{\circ} \mathrm{C}\right)$ \\
\hline & normal & (water) $\left(37^{\circ} \mathrm{C}\right)$ \\
\hline & normal & (water) $\left(20^{\circ} \mathrm{C}\right)$ \\
\hline & press & (water) $\left(50^{\circ} \mathrm{C}\right)$ \\
\hline & press & $($ water $)\left(37^{\circ} \mathrm{C}\right)$ \\
\hline & $\mathrm{p}$ & (water $\left.20^{\circ} \mathrm{C}\right)$ \\
\hline
\end{tabular}


ているように，重合時の温度と室温の差が小さいととに よるものと考えられる.

そして, 重合による収縮が加圧操作によって全て償却 されたとするならば，実際に収縮に関与する因子は熱膨 張係数だけだと考えられる.そこでガラス転移温度以下 で熱収縮が関与すると考えると silicone core type の Acron では $\left(105-20^{\circ} \mathrm{C}\right) \times\left(81 \times 10^{-6} /{ }^{\circ} \mathrm{C}\right) \times 100=$ $0.69 \%, \mathrm{QF}$ では $\left(107-20^{\circ} \mathrm{C}\right) \times\left(81 \times 10^{-6} /{ }^{\circ} \mathrm{C}\right) \times$

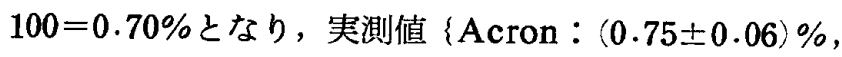
QF : $(0.57 \pm 0.02) \%\}$ に非常に近い值になっていた. plaster core type では Acron, QF とも理論值は $\left(96-20^{\circ} \mathrm{C}\right) \times\left(81 \times 10^{-6} /{ }^{\circ} \mathrm{C}\right) \times 100=0.62 \%$ であり実 測值 $\{$ Acron : $(0.47 \pm 0.01) \%, \mathrm{QF}:(0.42 \pm 0.02) \%\}$ と比較するとかなり大きな差がみられる．一方 self curing type resin である Repairsin をみると, この 場合は熱因子は重合熱しか働かない，予備実験ではこの

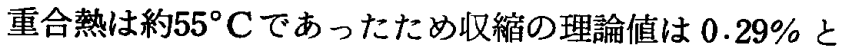
なり, silicone core type でみられた収縮率 $(0.28 \pm$ 0.04％に近似していだ. また Cast Resin の理論収縮 值は $0.22 \%$ で加圧typeの $(0.19 \pm 0.02) \%$ \%近似して いた。

この理論値と実測值の差が大きい plaster core type では石こうとレジンが接着し自由な変形が抢てらないの に対し, silicone core type では silicone とレジン が接着しないために比較的自由な変形が抢てりやすく， 石こう型では 内部応力がたくわえられやすいととにな る. 経時的変化をみると, 吸水試料, 乾燥試料とも変化 をおてし, 财水試料ではやや膨張する傾向があり, 乾燥 試料では収縮する傾向があった．乙の変化量の温度依存 性について調べると, 全試料について保存温度が高い程 変形量が大きくなっていた。しかも変形量は Acron,

QF, Repairsin では, silicone core type の方が plaster core typeより小さく, Cast Resin では加圧 type の方が normal type より小さい值であった.

重合後の変形速度の温度依存性についてみると, 保存 温度が高ければ早期より急激な変形速度を示し，しかも 変形速度が 0 に近づくのはほぼ $3 \sim 4$ 日後であるのに対 し, 保存温度が低くなると変形速度は小さくなるが, 速 度が 0 になるのは約 7 日後であり変形は徐々におてって いた。

つまり保存温度が高いほど変形が大きく, 内部応力の 解放が早いといえる。

C. 適合性試験
重合直後の変形率をるると plaster core type の Acron, QFでは，それぞれ $(1.40 \pm 0.06) \% ，(1.32 \pm$ 0.04\%\%であった. 一方 self curing type resin であ る Repairsin では, $(0.24 \pm 0.04) \%$, Cast Resinの

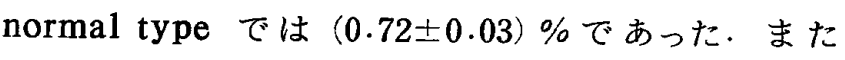
silicone core type では Acron, QF はそれぞれ $(1.03 \pm 0.10) \% ，(0.63 \pm 0.08) \%$ であったのに対し，

Repairsin では $(0.50 \pm 0.04) \%$, Cast Resin の加圧 type は $(0.39 \pm 0.05) \%$ であった。つまり silicone core type, plaster core type ともに加熱重合法を用 いるレシンの変形率に対して self curing type resin は約 $1 / 3 〜 1 / 2$ 值で著しく小さくなっていた．てれを統 計的にみると加熱重合法を用いるレジンと self curing type resin 間の重合直後の変形率には 高度に有意の差 があった。

また silicone core type と plaster core type を比 較すると, Acron, QF, Repairsin とも plaster core type の方が小さな変形率であり，統計的にみても三者 とも silicone core type と plaster core type の間 には高度に有意の差があったててのことは寸法安定性試 験と同様, レジンの dough の石こうに対する接着性と silicone に対する接着性の差によるものと思われる.

経時的変化をみると, 吸水試料, 乾燥試料とも変化を おこし, 吸水試料では開角し, 乾燥試料では開角する傾 向にあった．変形率の温度依存性についてみるとやはり 寸法安定性試験の場合と同じで，保存温度が高いほど大 きな変形率を示し，しかも早期に急激な変形率を示して いた.

すなわち加熱重合法を用いるレジンでも self curing type resin でも, モノマーの重合収縮は理論上同じで あるから，加熱重合法を用いるレジンの方が収縮量が大 きいのは硬化時に十分に高温になるため分子運動が活発 となり, 分子間凝集力の作用で強く凝集硬化するためと 考えられる. これに対し, self curing type resin は モノマーによりポリマーが結合されただけで相互に融合 していない状態のために変形が 小さいものと考えられ ろ.

また今回の実験では加熱重合法を用いるレジンの方が self curing type resinよりも内部応力の解放は大き くて早かった・このことは Osborn が常温重合したもの と加熱重合したものの内部応力の解放実験をした結果, self curing type resin は加熱重合法を用いるレジン の1/5〜1/3であったと述べているととと一致する。一方 silicone core type と plaster core type では plaster 
core type の方が内部応力の解放は大きくて早かった. つまりレシシンの種類でいえば加熱重合法を用いるレジ ンの寸法精度が self curing type resinより悪いこ と，埋没法でいえば石てう型に埋没したレジンの寸法精 度が silicone core typeより悪いととは，それぞれ冷 却中に生じた変形の度合と融通性がないとととが大きな 原因と考えられる.

self curing type resin の場合にはレシシンの重合が $\mathrm{Tg}$ 以下の温度で行れるので, 重合熱で上昇した温度か ら室温に冷却するまでの冷却による温度収縮があるだけ であるが，加熱重合型レジンは $\mathrm{Tg}$ から室温までの温度 差が温度収縮に関与するために内部応力の発生も硬化収 縮も大きいものと考えられる.

silicone core type の場合には silicone とレジン が接着しないために比較的自由な変形が可能でありし たがって収縮量は大きいが内部応力の発生は少ないもの といえる。

\section{結 論}

1. 内部忘力の発生はレジン混和後流動性のある状態 ではわずかであり，発生した内部応力が残留応力として 残るのはレジンがある程度 rigidになってからであった。

2. 比容積は加熱重合法を用いるレジンの方が self curing type resin より小さく, Tgは加熱重合法を用 いるレジンの方が高温であった。

3. 加圧重合法を用いる Acron, QF, Repairsin では, silicone core method の方が石てう埋没型のも のより比容積は小さく，Tg は高温であった。

4. Cast Resin では加圧操作を加えることにより比 容積を小さくすることができたが，Tgには影響がなか った。

5. 寸法精度については, 石てう埋没法, silicone core method ともに加熱重合法を用いるレジンよりも self curing type resin の方がよく, 前者に対して後 者は $1 / 2 \sim 1 / 3$ の収縮率であった。

6. 重合後の保存温度を高温にすると内部応力の解放 は早く変形量は大であった。

7. 通法に従って重合した self curing type resin は寸法精度が良いにもかかわらず $\mathrm{Tg}$ が低く，比容積が 大であるが，重合法を改良するてとによって Tg を上昇 させ，比容積を小さくするてとができた．

8. 以上のように silicone core method を用いる と Tg を上昇させ，比容積を娍少させることができ，内 部応力の発生量を抑えることができたが, 寸法精度の面
からみると精度がやや悪くなった。

9. self curing type resin より加熱重合法を用い るレシンンの方が内部応力の発生量が大きく, 寸法精度は 悪かった。

稿を終わるにあたり終始烈篤なで指導，で校閲を賜わ った恩師豊田静夫教授に対し，深甚なる感謝の意を表す るとともに，実験上数多くので教示をいただいた九州柬 科大学理工学教室林一郎教授, 井上勝一郎助教授, 小園 凱夫講師に心から感謝するとともに, 終始本研究にで協 力いただいた研究生執行由人先生をはじめ, 補緅学教室 員諸兄に厚く御礼申し上げます。

\section{引用 文 献}

1) 永井一夫 : アクリリックレジンの再検討, 歯界展望 $4: 16 \sim 17,1947$.

2 ）金竹哲也：粜科理工学通論, 末永書店, 東京, 19 $229 \sim 256$.

3）増原英一・春日均・他：コアーシステムによる金属 林，レジン床義菊の作り方， DE 38：1〜9， 1976.

4) Fairhulst, C. W. and Teth, C. D. : Tin-foil substitute : Warpage and crasing of acrylic resin, J.P.D. 4:274-287, 1954.

5 ) Ferguson, G. W. : Deficiencies of tin foil substitutes in the processing of acrylic resin, J.A.D.A.38:537-541, 1949.

6) Fairhulst, C.W. : Effect of tin foil substitute on the strength of denture base resin, J.P.D. $5: 508-512,1955$.

7) Shepard,W.L. and Colonel,L.: Denture base processed from a fluid resin, J.P.D. 19 : 561-572, 1963.

8 Koblitz, F. F. and Smith, R. A. : Fluid denture resin processing in a rigid mold, J.P.D. $30: 339-346,1973$.

9 ）鈴木暎・奥征男：レジン重合に対する圧の影響，歯 材器誌 $24: 1 \sim 61971$.

10) Woelfel, J. B. and Paffenbarger, G. C. : Dimensional changes occuring in dentures during processing, J.A.D. A. $61: 413-$ 415,1960 .

11）平沢忠：即硬性レシシンの重合硬化時の収縮につい て, 雬材研報 $2: 388 \sim 396,1962$. 
12）鈴木暎・宮治俊幸・他：寒天型によるレジン重合の 2,3 の問題, 歯材器誌 $29: 74 \sim 80,1973$.

13）増原英一，樽見二郎：歯材用レシンンの知識一常温重 合レジン一, 歯科技工 $2: 35 \sim 41,1974$.

14) McCracken, W. L. : Auxiliary uses of cold curing acrylic resins in prosthetic dentistry, J. A. D. A. $47: 289-304,1953$.

15) Jeffreys, F. E. : Use of self-curing resins in repairing and relining dentures, J.A. D. A. $44: 298-301,1950$.

16) Stanford,J.W. and Burns, C.L. : Self-curing resins for repairing dentures, J.A.D.A. $51: 307-315,1955$.

17) Brauer, G. M. and White, E. E. : Denture reliners-direct, hard, self-curing resin, J. A. D. A. $59: 270-283,1959$.

18) Peyton,F.A. and Anthony,D.H. : Evaluation of dentures processed by different techniques, J.P.D. 13:269-282, 1963.

19) Mowery,W.E. and Burns, C.L. : Dimensional stability of denture base resins, J.A.D. A. $51: 345-353,1958$.

20）増原英一・田中吉三：架橋剂による函科用メタクリ ル樹脂の内部気泡の消滅, 菌理工誌 $2: 48 \sim$ $54,1961$.

21）加藤仁朗・西井正道・他：各種ヒートショック型床 用樹脂の比較検討, 䨑材器誌 $17: 51 \sim 60$, 1968 .

22）藤井正道・堀部隆・他：加熱重合法と義菌床用レジ
ンの性質, 歯材器誌 $17: 28 \sim 34,1968$.

23）伊豆秀樹：床用流し込みレジン法における寒天溶 解, 保存法の一考案, 補綴臨床 4 ：300 304, 1971 .

24）松本直之・佐久間清文：流し込みレジンの加工精

度, 補経臨床 $4: 117 \sim 123,1971$.

25）安田登・佐藤浩・他：流し込みレジンのスプルー形 態と重合収縮, 人工曾の移動, 歯界展望 44 ： 498 512, 1974 .

26）熱田充：流し込みレジンの重合収縮に及ぼすスプル 一の位置と形態の影響について，補緅誌 18 ： 50 57, 1974.

27）林一郎・井上勝一郎・他：市販インレーワックスの 比容積変化について, 九棵誌 $24: 332 \sim 336$, 1970.

28）井上勝一郎：モノマー・ポリマー結合法によりポリ メタクリル酸メチルの粘弾性に関する基礎的研 究, 九䍘誌 $25: 443 \sim 465,1972$.

29）小野木重治：高分子の力学的性質, 化学同人, 東 京, 1965, 11-44.

30）原田義雄：義歯床用常温重合樹脂に関する研究，口 病誌 $32: 23 \sim 44,1965$.

31）増原英一・田中吉三：架橋重合した歯科用メタクリ ル樹脂の物理的性質について, 歯理工誌 2 ： 150,1961 .

32）平沢忠・山根正次・他：床用レジンをテストする, DE $17: 16,1971$.

33）三浦維四・林一郎・他：スキンナー菌科材料学, 医 師楽出版, 東京, 1969, 131-182. 